\title{
ARTITE
} Ipplied Resererrches in Technics, Technologies and Pductition Journal of the Faculty of Technics and Technologies, Trakia University https://sites.google.com/a/trakia-uni.bg/artte/

\section{AN OVERWIEW AND ANALYSIS OF DEPENDECIES FOR DETERMINING THE SATURATION PRESSURE OF WATER VAPORS}

\author{
Petko Tsankov, Ivan Binev \\ Faculty of Technics and Technologies, Trakia University \\ 38 Graf Ignatiev str., 8602 Yambol, Bulgaria, \\ e-mail: ptsankov@abv.bg, ivan.binev@trakia-uni.bg
}

\begin{abstract}
This paper reviews, describes and analyzes the accuracy of 24 dependencies for determining the partial pressure of saturated water vapor. An important indicator of this process is the partial pressure of water vapor in the air, and its maximum value is called saturated water vapor pressure or water vapor saturation pressure, or partial saturated water vapor pressure. The assessment is made against the accepted dependency of Hardy-Wexler. Conclusions and recommendations for simple and highly accurate dependencies $p_{s}=f(t)$ were made.
\end{abstract}

Keywords: partial saturation pressure of water vapor - $p_{s}$; accuracy of saturation pressure determination; dependencies for determining $p_{s}$.

\section{INTRODUCTION}

In order to reach a state of complete saturation, the air must absorb a certain amount of water vapor, which depends on the temperature and the total pressure. An important indicator of this process is the partial pressure of water vapor in the air, and its maximum value is called saturated water vapor pressure (or water vapor saturation pressure, or partial saturated water vapor pressure). It is referred to in various sources as $-p_{s}, p_{н п}, p_{w}, e_{s}$ or others notation.

The general type of dependence $p_{s}(t)$ is "exponential" - i.e. as the temperature increases, the saturation pressure increases. Figure 1 shows, in principle, this dependence on temperatures in the range $t=0 \ldots 100^{\circ} \mathrm{C}$.

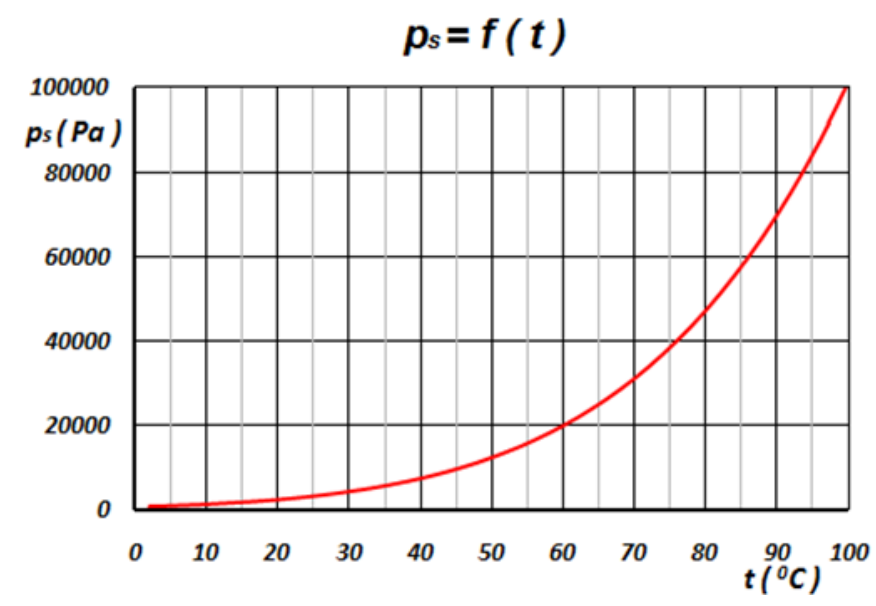

Figure 1. Water vapor saturation pressure as a function of temperature $p_{s}=f(t)$

Knowledge of this physical characteristic of humid air is important and necessary because it determines the nature and processes of climate and refrigeration, because it is related to the comfortable, meteorological and biological conditions of human life [1], [2].

IRTTIE Vol. 7, No. 4, 2019. ISSN 1314-8788 (print), ISSN 1314-8796 (online), doi: 10.15547/artte.2019.04.007 


\section{ARTTEY $Y$}

Ipplied Researlohes in Technics, Technologies and Bductition

Journal of the Faculty of Technics and Technologies, Trakia University https://sites.google.com/a/trakia-uni.bg/artte/

Various dependencies (approximations) have been published to calculate saturated water vapor pressure. These dependencies are of varying complexity and accuracy [10], [12, 13].

The purpose of this paper is to review, describe the various dependencies for determining the partial pressure of saturated water vapor, to analyze and evaluate the accuracy of the various dependencies.

\section{OVERVIEW OF THE BASIC DEPENDENCES FOR DETERMINING THE SESSION PRESSURE $P_{S}$}

The reasons for having so many studies and proposals for different dependencies describing the relationship between saturated water vapor pressure ps and temperature are both the importance of the question and the desire to achieve the highest possible accuracy in calculating ps at the relative simplicity of describing the analytical dependence.

Add to this the fact that, over time, with the development of technology, the accuracy of measurements of this physical characteristic $-p_{s}$, has improved, which has necessitated a change and updating of the descriptive dependencies [3], [5], [7], [8]. There are various, developed and improved over time International temperature scales - ITS-68, IPTS-68, ITS90. Legislators in this field are many international and technical organizations such as ASHRAE (American Society of Heating, Refrigerating and Air-Conditioning Engineers) [4], [6], [9], WMO (World Meteorological Organization) [11] and others.

Out of the many dependencies studied - $p_{s}(t)$, the work has been summarized and analyzed 24. They are summarized and given in Table 1, citing them based on their number or author. They are grouped by attribute - a community describing mathematical dependence. It can be summarized that the descriptive analytic dependencies used are of several types:

A. Indicative functions with the base "e" - known as "Magnus - formulas" (No. 1-5) and a generalized mathematical description:

$$
p_{s}=c \cdot e^{\frac{a \cdot t}{b+t}}
$$

B. Other types of indicator functions with base "e" (No. 6-9) and summarized mathematical description:

$$
\begin{gathered}
p_{s}=c . e^{\frac{a . t+b}{c+d . t}} \\
p_{s}=e^{a+\frac{b}{T}+c \cdot \ln T+d \cdot T} \\
p_{s}=d . e^{a+b . t+c . t . t .} \cdot \frac{t}{T}
\end{gathered}
$$

C. Indicative functions with basis "10" (No. 10-14) and summarized mathematical description:

$$
\begin{gathered}
p_{s}=a .10 \cdot e^{b \cdot \frac{t}{(c+t)}} \\
p_{s}=a .10 \cdot e^{\frac{b+c . t}{d+t}}
\end{gathered}
$$

D. Indicative functions with bases "e" and "10" and complex exponential polynomials (No. 15-20), with a generalized mathematical description:

$$
p_{s}=\exp \left(\sum_{i=1}^{6} a_{i} \cdot T_{i}^{i-2}+a_{7} \cdot \ln T\right)
$$

E. Other functions - polynomials indicative (No. 21-24).

IRITIE Vol. 7, No. 4, 2019. ISSN 1314-8788 (print), ISSN 1314-8796 (online), doi: 10.15547/artte.2019.04.007 


\section{ARTITE}

Ipplied Researrches in Technics, Technologies ind Educition

Journal of the Faculty of Technics and Technologies, Trakia University https://sites.google.com/a/trakia-uni.bg/artte/

In all generalized mathematical dependences $-a, b, c, d$-coefficients.

Table 1. Main dependencies for determining the saturation vapor pressure $p_{s}$

\begin{tabular}{|c|c|c|c|}
\hline № & Addiction - Content & Conditions & Authors \\
\hline \multicolumn{4}{|c|}{ A. Indicative functions with "e" basis - Magnus formulas } \\
\hline 1. & $p_{s}=611,21 . \exp [17,504 . t /(t+241,2)]$ & [Pa] & $\begin{array}{c}\text { GOST; } \\
\text { Bogoslovski }\end{array}$ \\
\hline 2. & $p_{s}=611,21 . \exp [17,27 \cdot t /(t+237,3)]$ & {$[\mathrm{Pa}]$} & Tetens-1 \\
\hline 3. & $p_{s}=610,94 . \exp [17,625 . t /(t+243,04)]$ & [Pa] & August-Roshe \\
\hline 4. & $p_{s}=611,21 . \exp [17,502 \cdot t /(240,97+t)]$ & {$[\mathrm{Pa}]$} & $\begin{array}{c}\text { Buck-1; } \\
\text { Romanov-1 }\end{array}$ \\
\hline 5. & $p_{s}=611,2 \cdot \exp [17,62 \cdot t /(243,12+t)]$ & [Pa] & Magnus-2 \\
\hline \multicolumn{4}{|c|}{ B. Other types of indicator functions with the basis "e" } \\
\hline 6. & $p_{s}=\exp (16,57 . t-115,72) /(233,77+0,997 . t)$ & $\left(t=0 \ldots 83^{0} \mathrm{C}\right),[\mathrm{kPa}]$ & $\begin{array}{l}\text { AVOK- } \\
\text { Tarabanov }\end{array}$ \\
\hline 7. & $\begin{array}{c}p_{s}=\exp (54,1945-6644,48 / T-4,115 \cdot \ln (T)- \\
-0,00134848 . T)\end{array}$ & $t=-60 . .60^{\circ} \mathrm{C},[\mathrm{Pa}]$ & Hardy \\
\hline 8. & $p_{s}=611,21 \cdot \exp \{(18,678-t / 234,5) \cdot[t /(257,14+t)]\}$ & [Pa] & Buck-2 \\
\hline 9. & $p_{s}=611,21 \cdot \exp \left[\left(19,846-8,97 \cdot 10^{-3} \cdot t+1,248 \cdot 10^{-5} \cdot t^{2}\right) \cdot t / T\right]$ & [Pa] & Romanov-2 \\
\hline \multicolumn{4}{|c|}{ C. Indicative functions with base "10" } \\
\hline 10. & $\begin{array}{l}\lg p_{s}=(156+8,12 . t) /(236+t) \\
p_{s}=133,3224 \cdot 10\end{array}$ & {$[\mathrm{~mm} \mathrm{Hg}],[\mathrm{Pa}]$} & $\begin{array}{c}\text { Filney, } \\
\text { Staroverov }\end{array}$ \\
\hline 11. & $p_{s}=10^{[10,19621-1 / 30,63 /(233,426+t)]}$ & [Pa] & Antoan \\
\hline 12. & $p_{s}=611 \cdot 10^{1,45 \cdot t /(23 /, 3+t)}$ & [Pa] & Magnus-1 \\
\hline 13. & $p_{s}=610,7 \cdot 10^{1,665 \cdot t /(243,33+t)}$ & [Pa] & Alduchov \\
\hline 14. & $p_{s}=611 \cdot 10^{1,5 \cdot t /(23 /, 3+t)}$ & {$[\mathrm{Pa}]$} & Tetens-2 \\
\hline \multicolumn{4}{|c|}{ D. Indicative functions with "e" and "10" bases and complex exponential polynomials } \\
\hline 15. & $\begin{array}{l}\ln p_{s}=-5,8002206 \cdot 10^{3} / T+1,3914993-4,8640239 \cdot 10^{-2} \cdot T+ \\
+4,1764768 \cdot 10^{-5} \cdot T^{2}-1,4452093 \cdot 10^{-8} \cdot T^{3}+6,5459673 \cdot \ln T\end{array}$ & $\begin{array}{c}T=273 \ldots 473 K \\
\left(t=0 \ldots 200^{\circ} \mathrm{C}\right),[\mathrm{Pa}]\end{array}$ & $\begin{array}{l}\text { Hyland - Wexler } \\
\text { ASHRAE }\end{array}$ \\
\hline 16. & $\begin{array}{c}\ln p_{s}=-2991,2729 \cdot T^{-2}-6017,0128 \cdot T^{-1}+18,87643854- \\
-0,02835472 \cdot T+1,7838301 \cdot 10^{-5} \cdot T^{2}-8,4150417 \cdot 10^{-10} \cdot T^{3}+ \\
+4,4412543 \cdot 10^{-13} \cdot T^{4}+2,858487 \cdot \ln T\end{array}$ & [Pa] & Wexler $A$. \\
\hline 17. & $\begin{array}{c}\ln p_{s}=-6096,9385 \cdot T^{-1}+16,63635794-2,711193 \cdot 10^{-2} \cdot T+ \\
1,673952 \cdot 10^{-5} \cdot T^{2}+2,433502 \cdot \ln T\end{array}$ & [hPa], ITS-90 & Sonntag- Heinze \\
\hline 18. & $\begin{array}{c}\text { In } p_{s}=-2836,5744 \cdot T^{-2}-6028,076559 \cdot T^{-1}+19,5426361- \\
-2,737830188 \cdot 10^{-2} \cdot T+1,6261698 \cdot 10^{-5} \cdot T^{2}+ \\
+7,0229056 \cdot 10^{-10} \cdot T^{3}-1,8680009 \cdot 10^{-13} \cdot T^{4}+2,7150305 \cdot \ln T\end{array}$ & [Pa], ITS-90 & Hardy - Wexler \\
\hline 19. & $\begin{array}{l}\lg p_{s}=-7,90298(373,16 / T-1)+5,02808 \cdot \lg (373,16 / T)+ \\
+1,3816 \cdot 10^{-7} \cdot\left[10^{11,344 \cdot(1-T / 373,16)}-1\right]+8,1328 \cdot 10^{-3} \cdot\left[10^{-3,49}\right) 49 \cdot(373,16 / \\
T-1)-1]+\lg 1013,246\end{array}$ & [hPa] & $\begin{array}{l}\text { Goff- } \\
\text { Gratch-1 }\end{array}$ \\
\hline 20. & $\begin{array}{c}\lg p_{s}=10,79574 \cdot(1-273,16 / T)-5,028 \cdot \lg (T / 273,16)+ \\
+1,50475 \cdot 10^{-4} \cdot\left[1-10_{1-273,16 / T)}^{-8,296 \cdot(T / 273,16-1)}\right]+0,7+0,42873 \cdot 10^{-3} \cdot\left[10^{4,76955 .(}\right. \\
\end{array}$ & [hPa] & $\begin{array}{l}\text { GOST } \\
\text { (Goff- } \\
\text { Gratch-2) } \\
\end{array}$ \\
\hline \multicolumn{4}{|c|}{ E. Other functions - polynomials, exponents } \\
\hline 21. & $p_{s}=\exp (77,34-7235 / T-8,2 \cdot \ln T+0,005711 . T)$ & [Pa] & Uni Helsinki \\
\hline 22. & $p_{s}=271,98 \cdot(0,01 \cdot T-1,623)^{8}$ & $t=0 \ldots 60^{\circ} \mathrm{C}[\mathrm{Pa}]$ & Sprav.OVK \\
\hline 23. & $p_{s}=479+(11,52+1,62 . t)^{2}$ & $t>0[\mathrm{~Pa}]$ & Russian \\
\hline 24. & $p_{s}=133,3224 \cdot \exp (20,386-5132 / T)$ & [Pa] & Wikipedia \\
\hline
\end{tabular}

\section{AN ANALYSIS OF THE ACCURACY OF THE DIFFERENT DEPENDENCES ON THE VACATION PRESSURE}

The accuracy of all these dependencies is estimated by the deviation (relative error) $\delta=f(T)$ of the saturation pressure $p_{s}$ from the accepted reference $p_{s}$ et for different approximations and is shown in the graphs in Figure 2.

A relative error is defined as:

$$
\delta=\frac{p_{s}-p_{s e t}}{p_{\text {s et }}}
$$

IRTTIE Vol. 7, No. 4, 2019. ISSN 1314-8788 (print), ISSN 1314-8796 (online), doi: 10.15547/artte.2019.04.007 


\section{IRTTIE}

Ipplied Researrohes in Technics, Technologies and Eductation

Journal of the Faculty of Technics and Technologies, Trakia University https://sites.google.com/a/trakia-uni.bg/artte/

18. Hardy - Wexler dependency is assumed to be the baseline reference for which the accuracy assessment is made.

$$
\delta=f(T)
$$

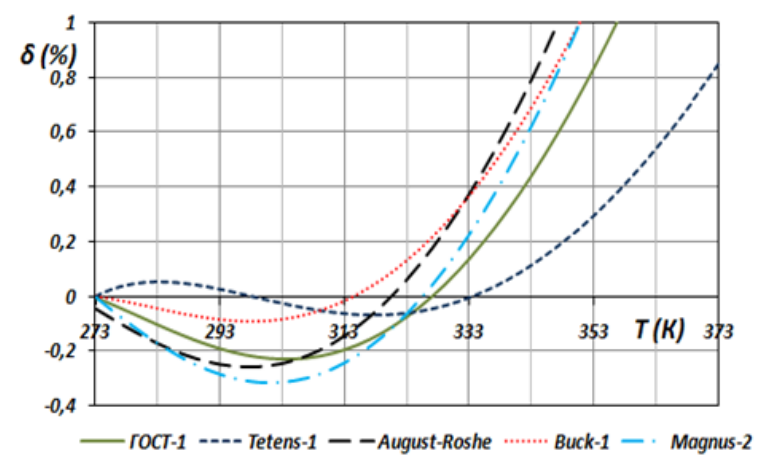

Figure 2 a. Indicative functions with the basis "e" - Magnus formulas (1-5)

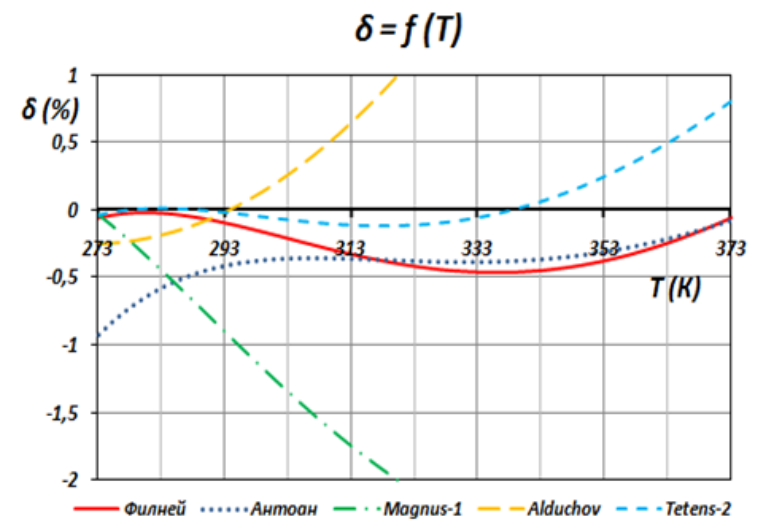

Figure 2 c. Indicative functions based on "10" (10-14)

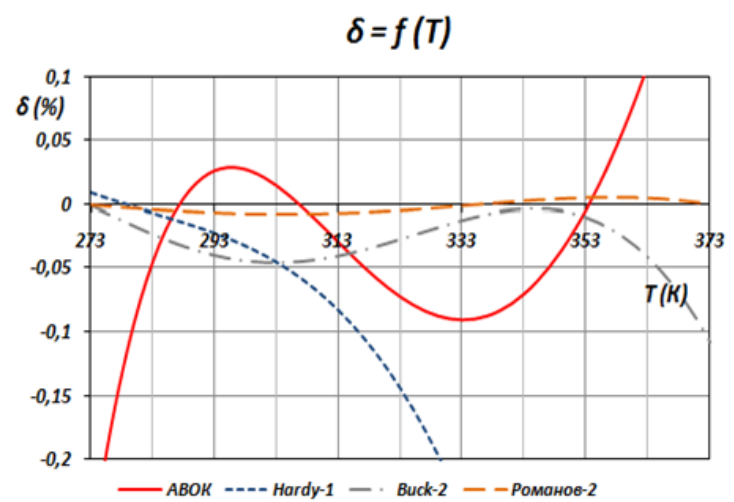

Figure 2 b. Other types of indicative functions with an "e" basis (6-9)

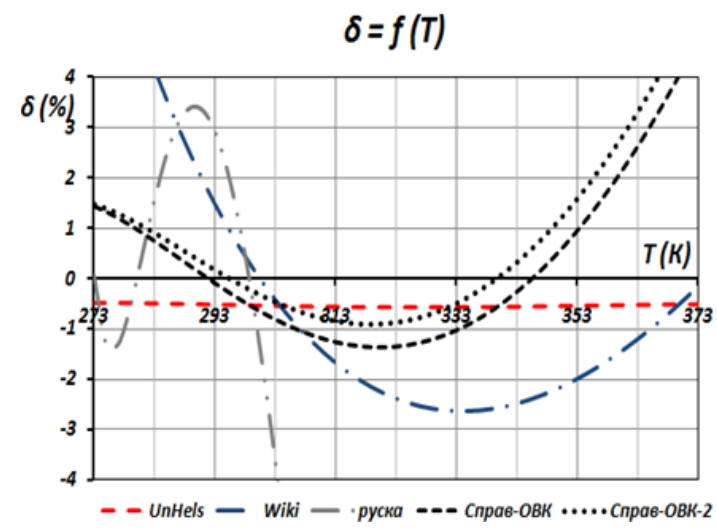

Figure $2 \mathrm{~d}$. Other functions - polynomials indicative (21-24)

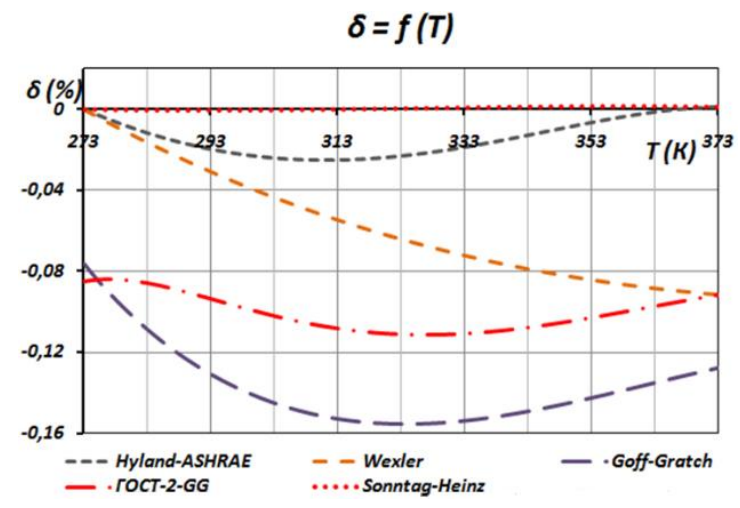

Figure 2 e. Indicative functions with bases "e" and "10" and complex indicator polynomials (15-20)

Figure 2. Saturation pressure deviation $\delta=f(T)$ with respect to base dependency "18. Hardy-Wexler"

IRTIIE Vol. 7, No. 4, 2019. ISSN 1314-8788 (print), ISSN 1314-8796 (online), doi: 10.15547/artte.2019.04.007 


\section{ARITIE}

Ipplied Resererches in Technics, Technologies and Pducition

Journal of the Faculty of Technics and Technologies, Trakia University https:///sites.google.com/a/trakia-uni.bg/artte/

The analysis of the results thus processed shows:

- among the dependences A (No. 1-5), the formula "2.Tetens-1" up to $t<600 \mathrm{C}$ shows relatively good accuracy $-\delta< \pm 0.1 \%$;

- the dependencies of group $E$ (No. 21-24) are the most inaccurate - for them the deviations are in the range of $\delta< \pm 3 \%$;

- in the second group of dependencies B (No. 6-9) the formulas of "9.Romanov-2” $\delta< \pm 0.01 \%$ and ",8.Buck-2" $\delta< \pm 0.05 \%$ stand out with their high accuracy. ;

- among the common dependencies of group C (№10... 14) high dependence in the working range has the dependence „14.Tetens-2” $-\delta< \pm 0.1 \%$, as well as "10.Filney" and "11.Antoan";

- the most accurate are the most complex analytical dependencies of group D (No. 15-20), among which the basic dependence is considered "18. Hardy-Wexler". For them the deviations are small $-\delta<-0,1 \%$.

It should be specified that the saturation pressure of water vapor in a multi-component system such as air (also referred to as effective effective saturation pressure - $p_{s}$ ) generally depends on both temperature and total pressure or:

$$
p_{s}^{\prime}=f\left(t, p_{a}\right)=k(p) \cdot p_{s}
$$

where $k(p)$ is a pressure correction function.

This correction is within $(0.45 \ldots 0.5) \%$ and is often not taken into account when determining the saturation pressure. The correction function can be determined depending on the type:

$$
k(p)=1,0016+3,1510^{-6} p-0,074 p^{-1}
$$

where $p$ is the total pressure, $[\mathrm{hPa}$.

Figure 3 shows the pressure-correcting pressure function $k(p)=f(p)$ determined by $(10)$ and WMO data.

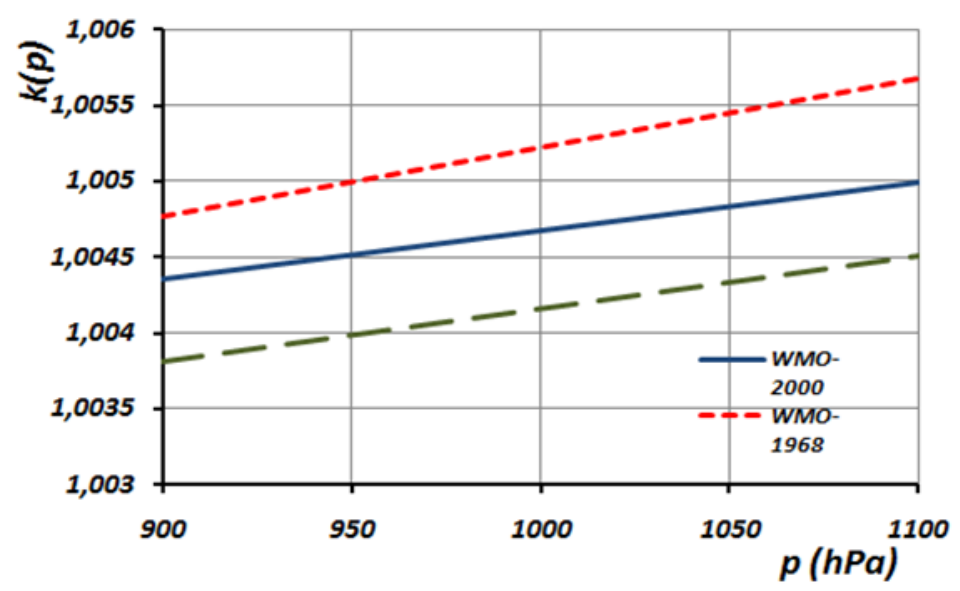

Figure 3.

Pressure - dependent pressure correction function $k(p)=f(p)$

IRTIIE Vol. 7, No. 4, 2019. ISSN 1314-8788 (print), ISSN 1314-8796 (online), doi: 10.15547/artte.2019.04.007 


\section{ARTTE $Y$}

Ipplied Researlohes in Technics, Technologies and Bductition

Journal of the Faculty of Technics and Technologies, Trakia University https://sites.google.com/a/trakia-uni.bg/artte/

\section{CONCLUSION}

In this work, 24 dependencies are investigated to determine the saturation pressure of water vapor ps.

An analysis of the dependencies and an assessment of their accuracy with respect to the base dependence of 18. Hardy-Wexler was performed. Recommendations for the use of approximation dependencies are determined by:

- the tasks assigned;

- the accuracy required;

- time and technical possibilities for using different dependencies;

- range of change in air temperature;

- influence of change in atmospheric pressure.

\section{REFERENCES}

[1] DEC Directory - Part 1 - Editor Prof. Stamov (1990). Publishing house "Tehnika", Sofia 1990, p. 312.

[2] GOST 8.524-85. (1985). Psychrometric tables - construction, content, calculated ratios Publishing house of standards, 1985, p. 37.

[3] Buck A. L. (1981). New equations for computing vapor pressure and enhancement factor. J. Appl. Meteorol., Vol. 20, pp. 1527-1532.

[4] Hardy B. (1998). ITS-90 Formulations for Vapor Pressure, Frostpoint Temperature, Dewpoint Temperature, and Enhancement Factors in the Range -100 to $+100{ }^{\circ} \mathrm{C}$. The Proceedings of the Third International Symposium on Humidity \& Moisture, London, England, April 1998.

[5] Hyland R. W., Wexler A. (1983). Formulations for the Thermodynamic Properties of the saturated Phases of $\mathrm{H}_{2} \mathrm{O}$ from 173.15K to 473.15K. ASHRAE Trans, Vol. 89, No. 2A, pp. 500-519.

[6] Murphy D. M., Koop T. (2005). Review of the vapour pressures of ice and supercooled water for atmospheric applications. Quart. J. Royal Met. Soc., Vol. 131, pp.1539-1565.

[7] Romanov N. P. (2009). A New formula for Saturated Water Steam Pressure within the Temperature Range -25 to $220^{\circ} \mathrm{C}$. Izvestiya AN. Fizika Atmosfery i Okeana, 2009, Vol. 45, No. 6, pp. 854-860.

[8] Sonntag D. (1994). Advancements in the field of hygrometry. Meteorol Z. N. F., Vol. 3, pp. 51-66.

[9] Wagner W., Pruß A. (2002). The IAPWS formulation 1995 for the thermodynamic properties of ordinary water substance for general and scientific use. J. Phys. Chem. Ref. Data, Vol. 31, pp. 387-535.

[10] Wexler A. (1976). Vapor Pressure Formulation for Water in Range 0 to $100^{\circ} \mathrm{C}$. A Revision. Journal of Research of the National Bureau of Standards, Vol. 80A, pp. 775785.

[11] World Meteorological Organization. (2008). Guide to Meteorological Instruments and Methods of Observation, Appendix 4B, WMO-No. 8 (CIMO Guide), Geneva 2008.

[12] Junzeng X. U., WEI Q., Shizhang P. (2012). Error of Saturation Vapor Pressure Calculated by Different Formulas and Its Effect on Calculation of Reference Evapotranspiration in High Latitude Cold Region. Procedia Engineering, Vol. 28, pp. 4348.

[13] Nedeva V., Zlatev Z., Atanasov S. (2012). Effective Resources Use for Virtual Laboratories through Cloud Computing and Services. Proceedings of ICVL 2012, The 7th International Conference on Virtual Learning, 2012, pp. 322-328.

IRTTIE Vol. 7, No. 4, 2019. ISSN 1314-8788 (print), ISSN 1314-8796 (online), doi: 10.15547/artte.2019.04.007 